\title{
SPATIAL PRODUCTIVITY AND COMMODITY, MATO GROSSO DO SUL - BRAZIL
}

\author{
LAMOSO, Lisandra Pereira ${ }^{{ }^{*}}$
}

(a) Phd in Geography. Professor Federal University of Grande Dourados (UFGD), Dourados (MS) Brazil. ORCID ID: https://orcid.org/00000002-5705-3280. CURRICULUM LATTES: http://lattes.cnpq.br/5623881752715097

\section{(*) CORRESPONDING AUTHOR}

Address: UFGD - Rodovia Dourados-Itahum, km 12, CEP: 79825-070, Dourados (MS), Brasil. Tel: (+55 67) 34102270

E-mail: LisandraLamoso@ufgd.edu.br

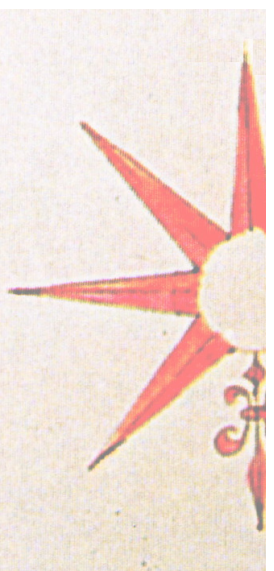

\begin{abstract}
This text aims to promote a reflection on the subject of the privileged geographical location that is credited to the State of Mato Grosso do Sul, analyzing the point of view of its trade relationships, based on the exports of commodities. This essay does not consider "logistic efficiency" as a given, as a value in itself. The relationships of production have not reached a level of maturity in a way that designs, defines and funds a technical apparatus that can be called "efficient" in its displacement costs. There is an unsatisfactory materiality that, if it does not compromise the international insertion of the state, at the very least weakens it. Methodologically, the notion of spatial productivity developed by Milton Santos is used. The reflections presented in this text may also be appropriate for cases in other units of the federation whose economic
\end{abstract} dynamics are based on the production of commodities.

Keywords: Spatial productivity; Logistic efficiency; Commodities; Geographic location.

\section{RESUMO / RESUMEN}

PRODUTIVIDADE ESPACIAL E COMMODITY, MATO GROSSO DO SUL - BRASIL

Este texto objetiva promover uma reflexão sobre o tema da localização geográfica privilegiada que é creditada ao Estado de Mato Grosso do Sul, analisando o ponto de vista de suas relações comerciais, baseadas nas exportações de commodities. Este ensaio não considera a "eficiência logística" como um dado absoluto, como um valor em si. As relações de produção não atingiram um nível de maturidade de forma a projetar, definir e financiar o aparato técnico que possa ser chamado de "eficiente" em seus custos de deslocamento. Há uma materialidade insatisfatória que, se não compromete a inserção internacional do estado, ao menos a enfraquece. Metodologicamente, utiliza a noção de produtividade espacial desenvolvido por Milton Santos. As reflexões neste texto apresentadas podem ser apropriadas também para casos de outras unidades da federação que tem sua dinâmica econômica baseada na produção de commodities.

Palavras-chave: Produtividade espacial; Eficiência logística; Commodities; Localização geográfica.

\section{PRODUCTIVIDAD ESPACIAL Y COMMODITY, MATO GROSSO DEL SUR - BRASIL}

Este texto tiene el objetivo de promover una reflexão sobre o tema de la ubicación geográfica privilegiada que es acreditada al Estado de Mato Grosso do Sul, analizando el punto de vista de sus relaciones comerciales, basadas en las exportaciones de commodities. Este ensayo no considera la "eficiencia logística" como un dato absoluto, como un valor en si mismo. Las relaciones de producción no alcanzaron maturidad de forma a proyectar, defender y financiar el aparato técnico que pueda ser llamado de "eficiente" en sus costos de displazamiento. Hay una materialidad insatisfactoria que, si no compromete la inserción internacional del estado, al menos la debilita. Metodologicamente, utiliza la noción de productividad espacial desarrollada por Milton Santos. Las reflexiones presentadas em este texto pueden ser apropiadas también para casos de otras unidades de la federación que tiene su dinámica económica basada en la producción de commodities.

Palabras claves: productividad espacial; eficiencia logística; commodities; ubicación geográfica. 


\section{INTRODUCTION}

Whenever it is necessary to characterize the state of Mato Grosso do Sul it is common to emphasize an economy that has as its main axis of accumulation the activities of agribusiness, highlighting livestock and grain production. Generalizations are useful though, from time to time, they need to be updated to confirm or propose a reinterpretation of the data. Some assertions about the State are emphasized with frequency and we get accustomed to them, sometimes rather carelessly. This text is deliberately written in the form of an essay, so as to propose that an understanding of reality also occurs in other ways, principally producing questions and counter-arguments (MENEGHETTI, 2011).

The objective of this essay is to question crystalized statements about the regional geography of Mato Grosso do Sul, with the intention of subsidizing an update of the interpretation of the State, going beyond the stereotypes propagated by marketing actions and studies with scanty empirical research. There are two statements that are problematized in the development of this text, from which we have updated some information about the infrastructure and the international insertion of the state's production. The reflections are permeated by a reading of the economy, prioritizing the analysis of economic activities derived from agricultural production and the process of industrialization, circulation and commercialization as factors producing geographical space.

The first point of enquiry concerns the State's "privileged position", a term used to describe the neighborhood shared with Paraguay and Bolivia, and the States of Paraná, São Paulo, Minas Gerais, Goiânia and Mato Grosso. It is also used to refer to its relative proximity to MERCOSUR countries. Considering these conditions as a privileged geographic position, associating it with the economic potential for international trade and for interstate exchange, incurs a misconception that ignores the targeting of State trade flows and disregards the expansion process of the urban network in Western Brazil. What criteria are used to assert that the state has a "privileged position"?

A second problematization addresses the supposed "logistic efficiency" in the northeast region of the state - the municipality of Três Lagoas and its surroundings - due to the presence of a stretch of the Ferronorte Railroad, the railroad axis administered by América Latina Logística (ALL - Malha Oeste) and by MS 262, all linking Mato Grosso do Sul to the state of São Paulo. Is there "logistic efficiency" in the northeastern portion of the state?

These two guiding questions (problematizations) make up this essay, in which we mobilize the concepts of Geographic Productivity and Logistics, as well as the definition of commodity, which is the starting point for the discussion.

Commodity refers to goods with a low industrial transformation and of little added value whose competition is established by prices and not by the differentiation of the product, since one of its characteristics is standardization, as, for example, with soy and iron ore, which are commodities present in Mato Grosso do Sul's exports. The volume of exports ${ }^{1}$ is indirectly linked to the degree of regional competitiveness. Castillo (2011) describes competitiveness as a geographical expression of production, complying with international parameters of quality and costs and corporate circulation.

The marketing of commodities requires a technical infrastructure network that provides stable, regular support and costs compatible with the full movement of cargo by internationalized corporations or agents that participate in the productive circuit. This technical network has different densities across the territory and helps to build the competitiveness of the region. ${ }^{2}$ This does not mean that they cannot incorporate technological development. The understanding in this essay is that even commodity-based economies can be drivers of R \& D investment, not only in the pro-

(1) A discussion on exports of Mato Grosso do Sul can be found in Lamoso (2010).

(2) For Castillo and Frederick (2010, p. 18), "the uneven distribution of material and normative densities in the territory confers different degrees of competitiveness to the regions for certain types of products and, therefore, to some of the productive agents acting therein and part of them". 
duct itself but also in the whole chain involving transport and storage, with increasingly modern techniques for efficiency gains.

The variation in commodity prices responds directly to international demands, to financial flows and also to the interest of corporations in the sector. "In the production spaces of commodities the vectors of globalization are intensely present". (LAMOSO, 2011, p. 597). It is necessary to emphasize that their commercialization is preferentially determined and executed by corporations even if, for certain products relevant to the production of Mato Grosso do Sul, corporations do not necessarily produce the basic goods, being only responsible for their commercialization, transportation and financing, as the case for trading in grains. Large companies are organized in networks that focus on their financial profitability, holding information, the key variable for the period (SANTOS, 1996), In regions producing commodities, as is the case of Mato Grosso do Sul, the object of this essay, the strategies and actions of this agent are ignored at the peril of mutilating our understanding of the production of geographic space.

In the commodity-producing complex (understood as the process of production and circulation of goods) there is a hiatus between production efficiency and circulation efficiency (again recalling the importance of transport costs to the commodity producer). There is a common sense saying that exemplifies this gap: "production is competitive from the gate inwards and loses competitiveness from the gate outwards". This hiatus is more present for midsize agents since corporations have the ability to press for large-scale public investments or even to implement them, in the flow of the grain production of the State of Mato Grosso.

Although capitalized, it is part of the accumulation strategy of large corporations to subordinate State planning to their interests in the definition of axes of circulation and, mainly, the implementation of transport and energy infrastructures. This increasing density of the technical apparatus is useful to the corporations by increasing productive specializations even more, in line with the interests of these hegemonic agents. ${ }^{3}$ Castillo proposes that in addition to the economic-financial meaning, there is also a political conception "that weakens and subjects the local producer - at least when it comes to agricultural commodities - to a single or global logic and to a situation over which there is no control, favoring buyers or large trading companies (tradings)" (CASTILLO, 2011, p. 340). In addition, he contributes to a synthesis that brings together a geographical definition of Logistics:

A set of material skills (infrastructures and equipment related to transport, storage, distribution, assembly of industrial products and customs premises, etc.), regulations (concession contracts, tax regimes, local transportation laws, tolls, local regulations for loading and unloading etc.) and operational (specialized knowledge held by service providers or logistical operators) that, gathered in a subspace, provide fluidity and competitiveness to economic agents and spatial productive circuits. This is the true corporate circulation. (CASTILLO, 2011, p. 339-340). (emphasis added).

Another notion that we are interested in incorporating into the discussion is that of Geographic Productivity or Spatial Productivity, which is complex because it does not refer only to natural data or to classic comparative advantages such as fertile land, climate, favorable soil conditions, or geometric location in physical space. It is a concept formulated by Santos (1996, p. 197) to observe that "places distinguish themselves by their different capacity to offer profitability to investments". The author states that profitability may be higher or lower according to local technical and organizational conditions, citing equipment, infrastructure, accessibility, local laws, taxes, labor relations and labor tradition. The strength of the notion of geographic productivity lies in recognizing the importance of natural conditions, but also adds the weight of artificially constructed conditions. Santos (1996) adds to geographic productivity the possibility of it not being lasting, since other places can become endowed with superior conditions to monetize capital and, as a result, this admits the assumption that "we live in a world where places show a tendency towards a faster aging (from a technical and

(3) For more information, see Frederico (2010), who presents a dense discussion about the characteristics of large grain exporting companies operating in Brazil. 
socioeconomic point of view), with different and even unexpected rhythms, depending on regions and countries". (SANTOS, 1996, p. 198). Also according to the author's theoretical proposal, this profitability is not absolute, but varies for certain products or activities and, with the acceleration of economic transformations, the world is the space available to large corporations, which are hegemonic agents in the production of commodities.

Having defined these concepts, which will guide our reflections on the aforementioned problematizations, this text is divided in two items, as well as this introduction and the final considerations, namely: Privileged geographical position and Logistic efficiency. When reflecting on these two points, the option herein is to invest in the presentation of information and data with a strong empirical appeal, in order to operationalize the concepts.

\section{PRIVILEGED GEOGRAPHIC POSITION}

The first reflection deals with a description of the geographical position: "Mato Grosso do Sul occupies a privileged position for trade. In the center of South America, it has boundaries with Paraná, São Paulo, Goiás and Mato Grosso and borders Bolivia and Paraguay, as well as having opportunities to trade with the MERCOSUR countries". This, or other similar terms is the recurring statement regarding geographical location that permeates both common sense and texts that start with an ostensibly geographical characterization.

The "privilege" seems to refer to geometrical data based on distance mileage and in the variety in neighbors, even when the topic is foreign trade. What is the parameter to be considered a "privilege"? The location of the State? Is it its centrality in the geometry of the continent?

Considering the historical process of occupation and settlement of the South American territory, it is evident that the predominance of the population and its main economic activities occur on the coasts of both the Pacific Ocean and the Atlantic Ocean. From a strictly economic point of view, ${ }^{4}$ being in the center cannot always be considered a privilege, although the Paraguay River served as an interiorization channel for river navigation as early as the eighteenth century.

Taking on the characteristics of a primary export economy, the main ports of Mato Grosso do Sul's production are the Port of Paranaguá, Port of Santos, Port of São Francisco do Sul and Port of Sobramil (Corumbá). Only the latter reveals a transportation advantage by using the Paraguay Waterway to reach the market of the Plate River basin and the Asian market, after transshipment of the goods at the Port of Nueva Palmira (Uruguay) or in Concepción (Argentina).

The continental area reduces the profit by including the cost of land freight and the port costs that are collected in the states of Paraná and São Paulo. With due proportions preserved, this is what happens when Minas Gerais goes through the port system of Espírito Santo or Rio de Janeiro. Taking an example - grain transported from the municipality of Dourados (MS) to the port of Paranaguá (PR) traverses $981 \mathrm{~km}$ with an average fuel cost of R\$1,500.00 plus R\$ 562.15 for road tolls, which together results in something around $\mathrm{R} \$ 2,062.15$, not including other expenses (insurance, port tariff, driver, vehicle depreciation/maintenance, etc.). ${ }^{5}$ The state does not have rail transportation between the producing regions and the main ocean ports, since the Railroad under concession to América Latina Logística was deactivated between Corumbá-Bauru (passing through Campo Grande and Três Lagoas) in the first semester of 2015.

It is also difficult to consider that the privileged geographic position serves trade with neighboring countries because there is a similarity in the export agenda of the countries of the Southern

(4) This text deliberately cuts a fraction of the totality by prioritizing the discussion about the process of economic development in function of the commercial relations that are established by the state with other countries and the state with other Brazilian states.

(5) Costs calculated for an articulated truck with two 27-ton trailers and 9 axes. Carriers charge an average cost between R\$ 160,00 to $\mathrm{R} \$ 180.00$ per ton, no less than $\mathrm{R} \$ 8,000.00$ for shipping 54 tons, which is the most common cargo in transit. (January 2016, data obtained in field work). 
Cone. Paraguay and Argentina ${ }^{6}$ export soy, along with Mato Grosso do Sul. Like Mato Grosso do Sul, Uruguay and Argentina also export beef. The main products exported by Paraguay in 2014 were soy, vegetable oil, beef and cereals (CENTRO DE ANÁLISIS Y DIFUSIÓN DE LA PARAGUAYA ECONOMY, 2015). In the same year, Argentina exported soybeans and by-products (bran, soybean oil), vehicles, corn, precious stones and metals, crude oil, plastic material and beef (AGÊNCIA BRASILEIRA DE PROMOÇÃO DE EXPORTAÇÕES E INVESTIMENTOS, 2015). Bolivia has exported oil, gas and derivatives, as well as minerals (which are the most traditional products on the agenda) and soybeans, ranking first among non-traditional producers (INSTITUTO BOLIVIANO DE TRÉ EXTERIOR, 2015). Mato Grosso do Sul's business relationship with Bolivia is based on imports of natural gas, which circulate through the Bolivia-Brazil gas pipeline (GASBOL) to the Southeast, being underused in the state itself. Bolivia has been the first country in the list of imports to Mato Grosso do Sul, representing 67\% in 2014. (Ministry of Development, Industry and Trade, 2015). The second was China (9.33\%), then Chile (4.28\%) and Paraguay (2.55\%), respectively (Ministry of Development, Industry and Trade, 2015). It is evident that the import of natural gas distorts the composition, flattening the Chinese participation, which effectively represents products used in the state. With regard to the state's exports, in 2014, 28.23\% of the total was destined to China, $10.04 \%$ to Argentina (iron ore) and $7.22 \%$ to the Russian Federation (beef) (MINISTRY OF DEVELOPMENT, INDUSTRY AND TRADE, 2015). Both in imports and exports, China's presence is crucial.

Three reflections synthesize the discussion on the "privileged geographical position". The first concerns the statement that starts from a static interpretation of geographical location and considers the fact of sharing international boundaries, being in the center of the South American continent and having borders with four Brazilian states a privilege. A privileged location is not an absolute data; it is dynamic and evaluated according to the criteria of interest. For business relationships established with the present productive structures, continental centrality does not have a favorable weight. The State is distant from the port system it uses and does little trade with Paraguay. It has exports to China through the port of Paranaguá or the port of Rio Grande. Its trade with Argentina is fairly limited to exports of iron ore by the Paraguay River; natural gas from Bolivia passes through the territory since the demand is greatest in the States of São Paulo and Rio Grande do Sul. The kilometric measurements say little about location if the relationships and direction of the flows in which the productive structures of the state participate are not understood. The productive structures depend on the implementation of technical networks that are efficient and, for the most part, require high investments with long-term returns. They demand economic and political settings that articulate corporate demands. The tradition of looking at continuous space is no longer sufficient because the logic of spatial contiguity must be replaced by the logic of discontinuity, by networked organization, in which points of the territory are related to distant ones, which do not even belong to a given region. ${ }^{7}$

\section{LOGISTIC EFFICIENCY}

The second problematization of this essay is a conceptual misconception found in the recurring references to "logistics infrastructure". We consider infrastructure as the technical objects that give physical support to services. Logistics represents strategy, planning and management (SILVEIRA, 2011). According to Silveira (2011, p. 23) "Logistics represents strategies (which can be competitive),

(6) For more information on Argentine exports, see Instituto Nacional de Estadística y Censos, 2015.

(7) Souza (2014) elaborates a didactic and enriching discussion about the concepts and scales of analysis, among them the concept of network. 
transport planning and management (which can be intermodal) as well as storage". ${ }^{8}$ In this sense, we must consider efficiency as a quality that belongs to a set of strategies, generally corporate, with the purpose of reducing the costs of transferring goods. In addition to corporations, the state also plays a leading role in formulating public policies and allocating resources that contribute to lower costs.

The infrastructure available for the circulation of goods in South-Matogrossense territory is limited and needs expansion, permanent maintenance and new investments to expand the technical network. As we shall see, some companies use the infrastructure within the existing concrete possibilities and as an adaptation of their needs mediated by the profitability that the transported product offers. One example of this interpretation is the case of iron ore. When the price was high, ${ }^{9}$ there was an initiative to form an association of companies to use the network of the Novoeste Railway (the current Western Network of América Latina Logística). When prices fell, the transport was dismembered. This raises the recurrent discussion about the need for intervention by the State as an inducing agent of the process of economic development, organizing the technification of the territory and not leaving it hostage to exclusively corporate interests. In the territories monopolized by commodities, investments in infrastructure follow the agents' interest; there is no long-term plan to develop competitive conditions and productive diversification, the plan is occasional and short-term.

Misleading references to "logistics" are not uncommon. For example, this occurs in statements that the northeast and east regions of Mato Grosso do Sul have an "efficient logistics infrastructure", in an attempt to refer to the short stretch of the Ferronorte and América Latina Logística's (ALL) railway tracks crossing the territory as a communication channel with the state of São Paulo.

The presence of railroads, highways or waterways is not, by itself, a defining factor in the reduction of transportation costs. Each type of goods requires a mode of transport (road, rail, air, river or maritime and, mainly, a combination of them) and equipment that is most suited to it. Although not defining, the higher the density of infrastructure, the greater possibility opened to logistics. Being close to the state of São Paulo does not represent a logistic efficiency, it only means that it is possible to access São Paulo's market and, mainly, the Port of Santos, traveling a shorter distance and not necessarily more efficiently. Otherwise, we would have to consider the average speed of twenty kilometers per hour of ALL wagons a "logistic efficiency"!

The presence of the railroad is not an absolute condition for the reduction of transport costs. Besides its physical existence in a certain region, the main issue is knowing the connections that it allows. Which point does it link to what point? Does it integrate with highways that are in a good condition? Are there yards and warehouses for storage? Really, the railroads are crystallized as objects that were traced in the past, when economic activity depended on other commodities and other market relationships. In Brazil the extensive network is drawn between economic regions that were producers of coffee, sugar and iron ore, linking the interior to ports on the Atlantic Ocean. They are poor integrators of the "economic archipelagos" whose role would subsequently be fulfilled by the expansion of the road system.

The main railroad in Mato Grosso do Sul cuts the state from East to West, coming from the State of São Paulo, along the stretch from Bauru-SP to Corumbá-MS, going through Três Lagoas and the capital Campo Grande. Is an important route because it lies more in the central part of the State and travels through the interior to link Brazil with Bolivia, as far as Santa Cruz de La Sierra.

In addition to the existence of this section, efficiency presupposes that as transportation, first it works and, second, that it has competitive costs. When we take the case of the railroad in question, none of these prerequisites is satisfactorily achieved, resulting in the circular equation that companies do not use the railroad because the conditions are bad and the conditions are bad because there is no demand from cargo.

(8) To deepen the concept of logistics and corporate logistics, cf. Silveira (2011).

(9) For example, in February 2011, a ton of iron ore was quoted at \$ 187 and in July 2015 the price was \$ 54. 
While recognizing the possibility of corporate management resolving the equation, if this does not happen, the State has a fundamental role as regulator and intervener, as the case may be.

Figure 1 shows the main road (in red) and railway (in dashed line, almost following the route of BR 262) axes. We can observe the short route of Ferronorte, in South-Matogrossense territory, in the east of the state, entering the state by the municipality of Chapadão do Sul and leaving through Três Lagoas, crossing the Paraná River, before entering the state of São Paulo. It has a gauge of 1.60 and connection points with Ferrovias Centro-Atlântica SA in Uberlândia (MG) and Ferrovias Bandeirantes (FERROBAN), in Santa Fé do Sul (SP).

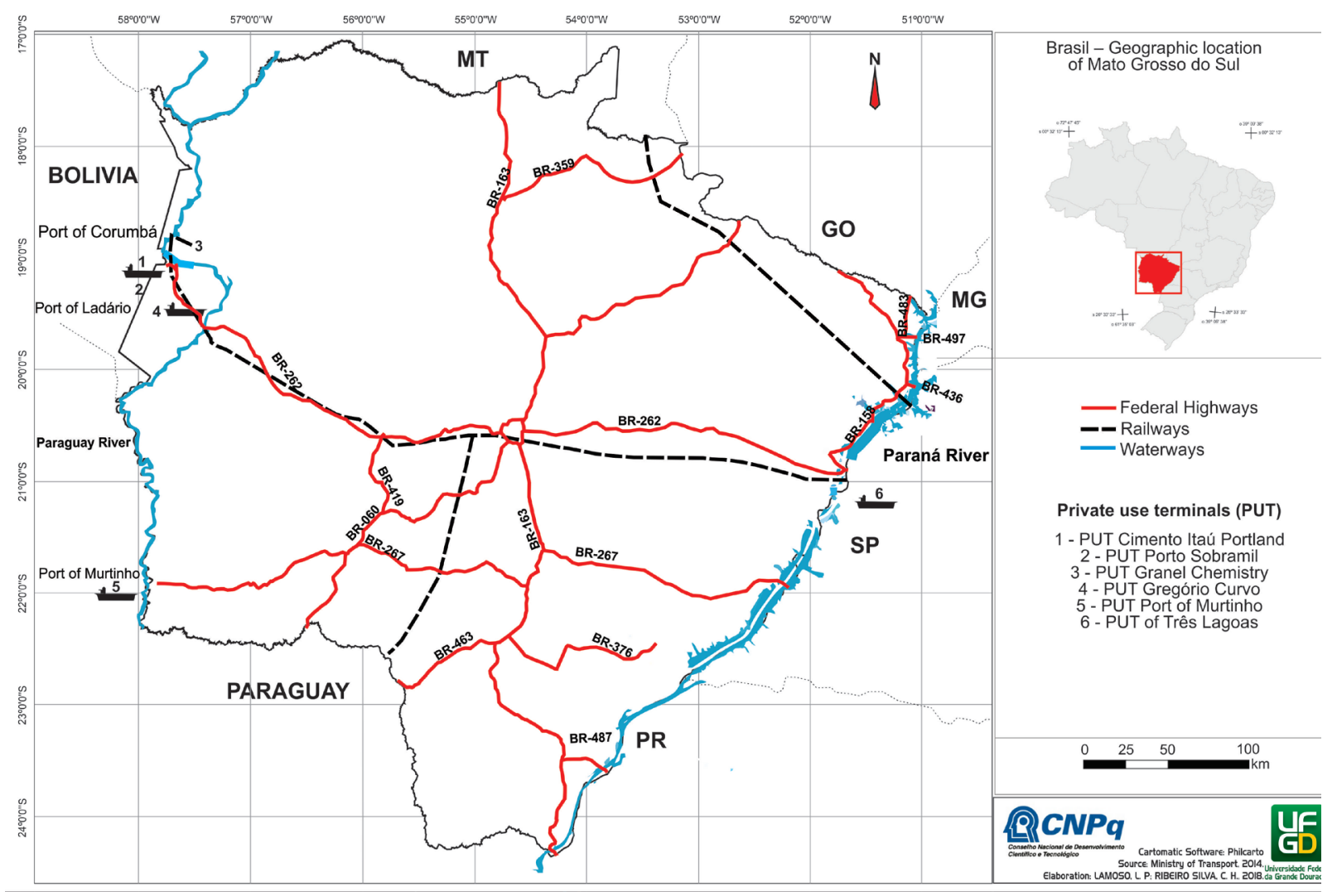

Figure 1 - MATO GROSSO DO SUL - Main highways and railroads - 2015

The main railroad is the ALL Malha Oeste (East-West in Figure 1). This Railroad (formerly Novoeste) is leased and operated by América Latina Logística (ALL) until 2026, with narrower meter gauge. It is 1,180 kilometers long, running between the city of Bauru (SP) to Corumbá (MS), following in the direction of Santa Cruz de La Sierra (Bolivia). It was the first stretch offered in 1996 to a group of US investors - the Noel Group, New York Investment Fund, associated with Edward Moyers, the former president of Southern Pacific. This group won the bidding against the Companhia Vale do Rio Doce (then a state-owned company) by paying a premium of 2.5 million reais on the price originally set at 59 million reais, with a concession for thirty years. Operating deficits and little investment in the restructuring of the line have been credited, by the concessionaire, for the loss of their main source of income at the time, transporting fuel ( $60 \%$ of revenues).

Under these conditions, the concessionaire joined Ferronorte, giving rise to Ferronorte Participações - Ferropasa, retaining $20.8 \%$ of the total capital. The holding Ferropasa was formed with $91 \%$ of the capital for Ferronorte and $9 \%$ of the capital for Novoeste, in 1998. The Novoeste concession contract was subrogated to Ferropasa. The participation of the North American group was sold to the Ferropasa shareholders and in that way the initial group, the first concessionaire, legally left the business of the concession, in a juridical form. In turn, Ferropasa, requested the Ministry of Transport to suspend the debt with the intention of applying to the BNDES for a loan for investments 
in reforming the structure, in order to increase the speed and reduce the number of accidents. The effects of these legal solutions remained until a new concession was made on behalf of América Latina Logística (ALL), which renewed expectations that the route would be resumed, with cargo transports. ALL, in turn, associated itself with Rumo Logística (of the Cosan Group) and the merger was approved by the Administrative Council for Economic Defense (CADE) in February 2015, for the management of América Latina Logística Malha Oeste S. A., the former Novoeste, whose original name was Noroeste do Brasil). Since the merger, the private planners decided to disable transportation on the stretch linking Bauru -Três Lagoas - Campo Grande - Corumbá alleging risks to trackside communities and the environment, because of the precariousness of the railroad that was transporting fuel (from the municipality of Paulínea-SP to Mato Grosso do Sul).

In the Ministry of Transport's last report (2013), the relation and quantity of products transported elucidated the difficulties of composing cargo for the Malha Oeste, because of the total transported in Useful Tonnage (TU) there was $76 \%$ of iron ore, $16.7 \%$ cellulose, $2.5 \%$ of fuels (gasoline, alcohol and diesel), $4 \%$ of steel products and $0.8 \%$ of other products. Iron ore is extracted in the Maciço do Urucum, in Corumbá.

This distribution of cargo, although all suitable for the rail transport mode, deserves a few comments in order to explain the conditions for the circulation of goods in the State. Iron ore from Corumbá, when transported by rail, is destined for the internal market, steelmakers located in the Southeast, but unlike the Carajás Railroad or the Vitória-Minas Railroad, it suffers from uneconomic transshipments along the route to the final destination. Before being placed in the wagons it is carried off-road by truck as far as the forecourt of the Maria Coelho Railway Station. In Bauru, it is transferred to trucks again to reach the steel mills. This process does not allow the use of the railroad to be designated as logistic efficiency and represents $76 \%$ of the loads. The railway is functional when the price of the ore and its derivatives is on the rise, offsetting its transshipment and transport.

Pulp is already practically in the arroyo of the Paraná River and does not use the railroad in the interior of Mato Grosso do Sul; it does so to enter the São Paulo network. Fuel cargo travels from Sao Paulo to Mato Grosso do Sul but given the improvement of road cargo transport (articulated trucks) and outsourced fleets of distributors, it has preferentially left the Refinery of Paulínia (REPLAN) by truck and not by train. Fuel, when it travels by truck, has the convenience of delivery directly to gas stations, which would not be possible with rail cargo as it would require transfer to trucks or storage tanks pending specific unloading. Among the iron and steel products is pig iron produced in Corumbá and bobbins and other Sitrel products, located in Três Lagoas, which have little circulation by the railroad in Mato Grosso do Sul as the production is destined to the market in São Paulo. The trucks have an average speed of 80 kilometers per hour whereas the freight trains from the Malha Oeste travel at $13.5 \mathrm{~km}$ per hour, on average, much like the rest of América Latina Logística's network (Table 1).

The condition of the network is the object of economic feasibility studies. One of these was conducted by the Institute of Logistics and Supply Chain that estimated the transport of 6 million tons per year. However, for the operation to become competitive the estimate is that a volume of 14.5 million tons per year is required to sustain the viability of the operation and investments estimated in the order of 1.4 billion reais. ${ }^{10}$ In spite of the fact that these types of strategic studies are not carried out by State planning bodies but by private consultants, it is likely that the estimate is close to the private groups' expectation to sustain long-term investments, to recover the network and acquire new equipment. This means that the volume of cargo is still low by the standards of the private sector and the investment high for the availability of public resources. An equation still under construction, with long political negotiations and that requires a financial architecture.

(10) Amounts conveyed in the report of the State Government of Mato Grosso do Sul, available at http://www.noticias.ms.gov. br/governo-reune-bancada-federal-para-apresentacao-de-estudos-de-viabilidade-da-malha-oeste-da-rumo-all/< Access on 28 Oct. $>2015$. 
When we turn our attention to the river port system, to cite that the state is "served" by the Paraguay River to the west and the Paraná River to the east, does not qualify in terms of logistics or river transportation. In order to have fluvial transportation, a waterway is needed, a technical apparatus that refunctions the natural data, that is, the presence of the river, so that its use as a means of transportation becomes possible and sustainable both environmentally and economically.

Table 1 - Characteristics of the average commercial speed and routes of the railway concessionaires - 2013

\begin{tabular}{c|c|c} 
& & \\
& Average Commercial Speed & Average speed of Route \\
\hline América Latina Logística Malha Norte S.A & 11,93 & 13.4 \\
\hline América Latina Logística Malha Oeste S.A & 11.64 & 13.5 \\
\hline América Latina Logística Malha Paulista S.A & 13.58 & 13.8 \\
\hline América Latina Logística Malha Sul S.A & 12.18 & 15.0 \\
\hline Estrada de Ferro Carajás & 23.96 & 48.0 \\
\hline Estrada de Ferro Paraná Oeste - Ferroeste & $10 / 22$ & 26.2 \\
\hline Estrada de Ferro Vitória-Minas & 24.22 & 41 \\
\hline Ferrovia Centro-Atlântica S.A & 14.42 & 23.1 \\
\hline Ferrovia Norte Sul & 17.17 & 34.9 \\
\hline Ferrovia Tereza Cristina S.A & 22.22 & 33.5 \\
\hline MRS Logística S.A & 15.35 & 13.2
\end{tabular}

Source: ANTT, 2013

Located on the Paraguay River are the River Port of Ladário (an important operational base for the Brazilian Navy in the Center-West) and the Private Use Terminals (TUP) of Cimento Itaú Portland S / A, Porto Sobramil, Granel Química, Gregorio Curvo, Porto Murtinho and the TUP of Três Lagoas is located on the Paraná River. The operation of the TUPs already indicates the productive base that gives them support in a very didactic manner. The Itaú Portland Cement TUP has demand for its own product, its production in Corumbá relies on the availability of raw materials, in addition to policies to protect the domestic market that was undertaken during the strengthening of the import substitution process. Sobramil and Gregório Curvo are operated by Vale, ${ }^{11}$ with yards for iron ore and manganese to serve Plate basin market. Gregorio Curvo was formerly owned by Mineração Corumbaense (Rio Tinto), which was acquired by Vale. Granel Química transports grains and the TUP de Murtinho had been deactivated. It was reopened in October 2015, after an investment of 1 million dollars. This is the most diversified in terms of cargo, because the its location in the southern part of the state allows the attraction of cargos of sugar, soy and corn. It is operated by the Port Agency of Porto Murtinho (APPM), which takes advantage of the dollar exchange rate to obtain better prices for commodities produced in the state. The TUP of Três Lagoas serves the pulp sector, which reaches the Tietê River (São Paulo) to place the cargo in the Port of Santos. It has water deficit issues but there is a captive demand to sustain its operations.

Returning to the subtitle of this discussion, "logistical efficiency" is still something under construction, it cannot be read only with a map of the state, but must contextualize the map of the Center-West on the world map and observe the access to the main seaports. If this is taken as a given, it is evident that rail access to Paranaguá is a priority project in the search for efficiency and logistics. This necessitates: the construction of a grain terminal in the municipalities of Maracaju and Dourados, the extension of the railroad between the cities of Maracaju and Dourados and the Dourados - Cascavel - Paranaguá route (a Ferroeste project, still in economic feasibility studies).

(11) The Companhia Vale do Rio Doce, which was privatized in 1997, one of the largest iron ore extraction companies in the world. 
Without the rail link to the port, which is a structural project for planning the outflow of the harvest, the products of Mato Grosso do Sul (and even the tax collection of the State) are undermined by freight costs; consequently, competitiveness is reduced. The aforementioned conditions are workable because of the price of grains in the international market and are tied to the exchange variation. The exchange and the external market are direct vectors in the arrangement of the productive structures and in the technical network of the state. ${ }^{12}$

The state's main highway is the BR 163, which crosses it from north to south, connecting the states of Mato Grosso and Paraná, two important grain producers, through the port of Paranaguá. Paraná is the destination for a good part of the soybean and corn exports of the producing states of the South and Mato Grosso do Sul. Until 2014, this important national integration highway had badly maintained, single lanes. It was only in 2015 that the works of the CCR MSVia concession progressed and the routes in the State began to be duplicated and, therefore, tolled. Considering that the State uses the highway for the disposal of the harvest and that it only became profitable for a private concession in 2013, indicates the deficiency in the transport infrastructure in force until then.

The BR 262, from east to west, between Corumbá - Campo Grande - Três Lagoas is single lane. Its busiest stretch, which is from the State capital toward the State of Sao Paulo passing by Três Lagoas, has not received offers from concessionaires or any private national group interested in road-widening projects, even considering the movement of pulp and paper, in the northeast of the State, the Bolsão region.

In short, information about "logistics efficiency" has to be put into perspective, because the technical network currently deployed, which effectively allows the fluidity, has unresolved issues that perpetuate their degree of strangulation: as in the case of the Malha Oeste and the inadequacy of the waterways and the BR $262 .{ }^{13}$

In addition to agricultural production, the State of Mato Grosso do Sul has the mineral extraction of iron and manganese consolidated in the municipality of Corumbá, in the South-Matogrossense Pantanal, in the Morraria do Urucum. The global reserves of iron ore total 170 billion tons and Brazil has $13.6 \%$ of this total, with an average iron content of $49.0 \%$ (NATIONAL DEPARTMENT OF MINERAL PRODUCTION, 2014).

Mato Grosso do Sul's share in the total national reserves of iron ore is $13.1 \%$ (Minas Gerais - 72.5\% and Pará 10.7\%). The ratio changes when it comes to production, which is distributed in the following proportions: Minas Gerais (68.8\%), Pará (27.3\%), Mato Grosso do Sul (2.0\%) and Amapá (1.6\%) (NATIONAL DEPARTMENT OF MINERAL PRODUCTION, 2014). With respect to manganese, the distribution of the national production is $15 \%$ in Minas Gerais, $14.6 \%$ in Mato Grosso do Sul and $70 \%$ in the State of Pará (NATIONAL DEPARTMENT OF MINERAL PRODUCTION, 2014). (Table 2)

Table 2 - Percentage distribution of Brazilian production of iron ore and manganese-2013

\begin{tabular}{c|c|c} 
States & Iron Ore & Manganese ore \\
\hline Pará & 27.3 & 70.0 \\
\hline Minas Gerais & 68.8 & 15.0 \\
\hline Mato Grosso do Sul & 2.0 & $14-6$ \\
\hline Amapá & 1.6 & -- \\
\hline Other States & 0.7 & 0.6
\end{tabular}

Source: DNPM, 2014

Organized by Lamoso

(12) Prates and Marçal (2008) explore in detail the relationship between commodities and exports, registering two elements: The China effect and global macroeconomic conditions.

(13) Works by Andrade (2016) and Pareja (2016) present details on the transportation of pulp production from the plants located in Três Lagoas and from iron ore and manganese, from mining in Corumbá, respectively. 
For mineral exploration, as a supplier of ore with little beneficiation, the Paraguay River Waterway it is essential and, like grain, the price of the commodity must compensate its of extraction and transportation costs.

\section{FINAL CONSIDERATIONS}

To summarize, we understand that there is no technical density and satisfactory infrastructure availability to qualify as "logistic efficiency" in any of the mesoregions or the state as a whole. The route of the main modal axes is quite reasonable, since the capital is in the center of the territory, with three important municipalities in extremes to the west (Corumbá), east (Três Lagoas) and south (Dourados), with the service of the BR 163 (north to south), the BR 262 (east to west), the ALL railroad (east to west) and the stretch of the Ferronorte (east region), as well as the Paraguay Waterway (East) and Paraná Waterway (West). This physical, almost symmetrical / geometric distribution is an underused potential given that its operating conditions are compromised or limited by lack of investment.

In the Paraguay Waterway, navigability conditions fluctuate with natural periods of floods and droughts, reducing the capacity of the trains, the BR 163 is not yet fully duplicated, the others are single lanes. The railway (even under the concessionaire) does not have an efficient service and the Paraná Waterway is underutilized for the transport of cargo originating in Mato Grosso do Sul. The scale of production of goods has not yet reached, and might not reach, a sufficient volume to attract investments from the private sector, even in the form of public-private partnerships and investments in infrastructure by the public authorities seems compromised both by the absence of financial engineering as by the inability of national territorial planning, whose fragmentation compromises the planning (VAINER, 2007), currently held hostage to parliamentary amendments and the vision of private consultancy companies, always activated to design territorial use for corporate practices.

Geographical location is not an absolute given, a value in itself. It is a quality established from criteria and benchmarks to which the measures of distance or neighborhood are relative; they depend on the predominant economic interest. If there is an intense economic integration in order to export and import with China, for the countries affected by the port system installed on the Atlantic coast, it is not a privileged geographic position to be in the interior of the continent. In terms of foreign trade and strictly about it, a privileged geographic position is a possibility, which could materialize if economic integration with Plate basin countries were strengthened.

The technical network, formed by the infrastructure that makes transport possible, does not impose productive superiority on the territory or the regions. The production and social relationships are what design and execute the technical network for their interests of accumulation. The more consolidated social relationships are around a project of accumulation, the more the territory in which they [the social relationships] are inserted will be endowed with technical objects capable of increasing the productivity of this space.

For this reason, we do not comprehend "logistic efficiency" as an absolute data, as a value in itself, but as a social construct and, as such, not yet consolidated in South-Matogrossense territory. Relationships of production have not reached a level of maturity that can design, defend and fund a technical apparatus that can be called efficient for transport planning. There is an unsatisfactory materiality that is not committed to the international insertion of the state, or at least weaken it. It is a state of agribusiness, a producer of commodities, which accounts for less than $2 \%$ of the total Brazilian exports.

\section{ACKNOWLEDGMENTS}

The author is grateful to CNPq for the scholarship and the researchers Cristóvão Ribeiro da Silva and Giovane Silveira da Silveira for the support with the cartographic work. 


\section{BIBLIOGRAPHIC REFERENCE}

AGÊNCIA BRASILEIRA DE PROMOÇÃO DE EXPORTAÇÕES E INVESTIMENTOS. Exportações brasileiras e os ciclos de commodities: tendências recentes e perspectivas. Brasília : APEX, jul.2011.

AGÊNCIA nACIONAL DE TRANSPORTES TERRESTRES. Rumo Malha Oeste S/A. Disponível em http://www.antt.gov.br/ferrovias/America_Latina_Logistica_Malha_Oeste_SA.html

ANDRADE, Vinícius de Souza. O setor de celulose e papel em Três Lagoas-MS: Inserção no mercado internacional e transformações logísticas. In: LAMOSO, Lisandra. Relações internacionais de Mato Grosso do Sul. Curitiba : Íthala, 2016.

BERNARDES, Julia Adão; ARACRI, Luis Angelo dos Santos (orgs.). Espaço e circuitos produtivos. Rio de Janeiro : Arquimedes, 2010.

CASTILLO, Ricardo Abid. Agricultura globalizada e logística nos cerrados brasileiros. In: SILVEIRA, Márcio Rogério (org). Circulação, transportes e logística. São Paulo : Outras Expressões, 2011. p.311-354 CASTILLO, Ricardo; FREDERICO, Samuel. DINÂMICA REGIONAL E GLOBALIZAÇÃO: espaços competitivos agrícolas no território brasileiro. Mercator, 2010. V.9, n.18, 17-26. Disponível em http://www. mercator.ufc.br/mercator/artcle/view/330. <Acesso em 21 fev. 2016>

CENTRO DE ANÁLISIS Y DIFUSIÓN DE LA ECONOMIA PARAGUAYA.Datos de exportación, importación y reexportación. Asunción : CADEP, 2015. Disponível em http://www.cadep.org.py/OBEI/ inicio. <Acesso em 9nov 2015>

DEPARTAMENTO NACIONAL DE PRODUÇÃO MINERAL. Sumário Mineral 2014. v.34. Brasília : DNPM, 2014.

FREDERICO, Samuel. O novo tempo do Cerrado. São Paulo : Annablume/FAPESP, 2010.

INSTITUTO BOLIVIANO DE COMÉRCIO EXTERIOR. Boletim eletrônico de comércio exterior. La Paz : IBCE, 2015. < Disponível em http://ibce.org.bo/images/ibcecifras_documentos/CIFRAS-460-Exportaciones-Septiembre-2015.pdf

INSTITUTO NACIONAL DE ESTADÍSTICA Y CENSOS. Origen provincial de las exportaciones argentinas - 2014. Buenos Aires : INDEC, 2015. Disponível em http://www.opex.indec.gov.ar/. <Acesso em 9 nov 2015>.

LAMOSO, Lisandra Pereira. Commodities. In: SILVEIRA, M. R. (org.). Circulação, transportes e logística. São Paulo : Outras Expressões, 2011.

LAMOSO, Lisandra Pereira. Dinâmicas produtivas da economia de exportação no Mato Grosso do Sul Brasil. Mercator, Fortaleza, v. 10, n. 21, p. 33 a 47, apr. 2011. ISSN 1984-2201. Disponível em: <http:// www.mercator.ufc.br/mercator/article/view/418>. Acessado em 14 feb. 2018.

MENEGHETTI, Francis Kanashiro. O que é um ensaio-teórico? RAC, Curitiba, v. 15, n. 2, pp. 320-332, Mar./Abr. 2011 Disponível em <http://www.scielo.br/pdf/rac/v15n2/v15n2a10.pdf>

MINISTÉRIO DO DESENVOLVIMENTO, INDÚSTRIA E COMÉRCIO. Estatísticas de comércio exterior. Disponível em http://www.mdic.gov.br//sitio/interna/interna.php?area=5\&menu=1076

MINISTÉRIO DOS TRANSPORTES. Acompanhamento das concessões ferroviárias - relatório anual GEROF/SUFER. Agência Nacional de Transportes Terrestres (ANTT). Brasília, 2014.

PAREJA, Gabriel Narciso. Logística e relações de mercado na produção de minério de ferro de Mato Grosso do Sul. In: LAMOSO, Lisandra. Relações internacionais de Mato Grosso do Sul. Curitiba : Íthala, 2016.

PRATES, Daniela; MARÇAL, Emerson Fernandes. O papel do ciclo de preços das commodities no desempenho recente das exportações brasileiras. Revista Análise Econômica, Porto Alegre, ano 26, n. 49, p. 163-191, março de 2008.

SANTOS, Milton. A Natureza do Espaço: Técnica e Tempo. Razão e Emoção. São Paulo : Hucitec, 1996. SILVEIRA, Márcio Rogério. Geografia da Circulação, Transportes e Logística. In: transportes e logística. São Paulo: Outras Expressões, 2011. p. 21-69. . (org). Circulação,

SOUZA, Marcelo Lopes de. Os conceitos fundamentais da pesquisa sócio-espacial. Rio de Janeiro: Bertrand, 2014. 
VAINER, Carlos. Fragmentação e projeto nacional: desafios para o planejamento territorial. Anais. XII Encontro da Associação nacional de Pós-graduação e Pesquisa em Planejamento Urbano e Regional. Belém : ANPUR, 2007. 